\title{
Bitkinin fosfor alımına vermikompost ve farklı fosfor dozlarının birlikte etkisi*
}

\author{
The effects of vermicompost and different phosphorus doses on phosphorus uptake of \\ the plant
}

\section{Emre VURGUN@, Nuray Mücellâ MÜFTÜOĞLUĐ}

Çanakkale Onsekiz Mart Üniversitesi, Ziraat Fakültesi, Toprak Bilimi ve Bitki Besleme Bölümü, 17100, Çanakkale, Türkiye

Sorumlu yazar (Corresponding author): N. M. Müftüoğlu, e-posta (e-mail): mucella@comu.edu.tr

Yazar(lar) e-posta (Author e-mail): emre.vrgn@outlook.com

\section{MAKALE BİLGİSİ}

Alınış tarihi 24 Temmuz 2019

Düzeltilme tarihi 27 Eylül 2019

Kabul tarihi 27 Eylül 2019

\section{Anahtar Kelimeler:}

Fosfor

Marul

Perlit

Vermikompost

\begin{abstract}
ÖZ
$\mathrm{Bu}$ çalışmada, organik bir gübre olan vermikompostun fosfor elementinin alınabilir forma geçmesi üzerine etkisi araştırılmıştır. Daha önce yurtdışında ve ülkemizde yapılan çalışmalar göz önüne alındığında, vermikompostun bitkinin verimlilik parametreleri üzerinde etkili olduğu saptanmıştır. Ancak vermikompost ile birlikte kullanımından dolayı elementlerin alınabilir forma geçmedeki etkisi konusunda çok az çalışma bulunmaktadır. Araştırmada; organik gübre olarak vermikompost $\left(1000 \mathrm{~kg} \mathrm{da}^{-1}\right)$, yetiștirme ortamı olarak perlit, bitki olarak da marul (Lactuca sativa L.) bitkisi kullanılmıştır. Fosfor uygulaması $(0,5,10,15$ ve $20 \mathrm{~kg}$ $\mathrm{P}_{2} \mathrm{O}_{5} \mathrm{da}^{-1}$ ) için triplesüper fosfat gübresi kullanılmıştır. Elde edilecek olan sonuçlara göre kimyasal gübrelerin kullanımının sınırlandırılması ve toprak verimliliğinin sürdürülebilir olması amaçlanmıştır. Çalışma ile fosfor elementinin alınabilirliğini vermikompostun nasıl etkilendiğinin belirlenmesi hedeflenmiştir. Ayrıca verim ve verim parametreleri de incelenmiştir. Sonuç olarak; bitkideki fosfor miktarının, yeşil olarak tüketilmesi durumunda alınan fosfor miktarının ve marul bitkisi verimi oluştururken ortamdan en fazla sömürülen fosfor miktarının uygulanan $10 \mathrm{~kg} \mathrm{P}_{2} \mathrm{O}_{5} \mathrm{da}^{-1}$ miktarına kadar arttığı bu dozdan sonra azaldığ 1 saptanmıştır.
\end{abstract}

\section{ARTICLE INFO}

Received 24 July 2019

Received in revised form 27 September 2019

Accepted 27 September 2019

\section{Keywords:}

Lettuce

Perlite

Phosphorus

Vermicompost

\begin{abstract}
In this study, the effect of vermicompost, an organic fertilizer, on the conversion of phosphorus element to the available form was investigated. It has been determined that vermicompost has an effect on the productivity parameters when some studies done abroad and in our country are taken into consideration. However, due to the use of vermicompost there is very little work on the effect of elements on the viability and the effect of plant nutrient uptake. In the study, vermicompost $\left(1000 \mathrm{~kg} \mathrm{da}^{-1}\right)$ as manure, perlite as medium and lettuce (Lactuca sativa L.) plant as plant were used. Triplesuper phosphate was used as phosphorus source $\left(0,5,10,15\right.$ and $\left.20 \mathrm{~kg} \mathrm{P}_{2} \mathrm{O}_{5} \mathrm{da}^{-1}\right)$. According to the results obtained, it is aimed that chemical fertilizers should be used excessively, production inputs should be reduced, the use of chemical fertilizers should be limited, and soil fertility should be sustainable. In this study, we aim to determine the effect of the phosphorus element uptake. In addition, yield and yield characteristics are examined. As a result, it was found that the amount of phosphorus in the plant, amount of phosphorus in green consumed plant, the amount of phosphorus uptake from the medium, yield, up to $10 \mathrm{~kg} \mathrm{P}_{2} \mathrm{O}_{5} \mathrm{da}^{-1}$ increased up applied was reduced after this dose.
\end{abstract}

*Bu makale "Vermikompostun Fosfor Alınımı Üzerine Etkisi” başlıklı tez kapsamından üretilmiş olup, Uluslararası Avrasya Doğal Beslenme ve Sağlıklı Yaşam Zirvesi'nde özet bildiri olarak sunulmuştur.

\section{Giriş}

Kimyasal gübrelerin kullanımı topraklarda fiziksel, kimyasal ve biyolojik sorunları da beraberinde getirmiştir. Meydana gelen birçok çevre sorunu insanları kimyasal gübrelerden uzaklaştırıp, sürdürülebilir toprak verimliliğini göz önünde bulundurarak organik gübrelere yöneltmiştir. Dünyanın en büyük sorunlarından biri olan çevre kirliliğini azaltmak ve ekosistemin dengesini korumak gerekmektedir. Organik gübreler bitkilere besin kaynağı olmalarının yanı sıra çevreyi kirletmeden doğal dengeyi korumakta, bitkisel üretimde verim ve kaliteyi yükseltmekte, toprak düzenleyicisi görevlerini de yerine getirmektedirler. Toprak ekosistemini korumak ve sürdürülebilir tarımsal verimliliği arttırmak için organik gübre 
kullanımını artırmak, tarımın sürdürülebilir olmasını sağlamak ve geleceğe ait doğru planlamalar yapabilmek için öncelikle toprağı çok iyi tanımak ve bilmek, bunun için fiziksel, kimyasal ve biyolojik özelliklerinin doğru olarak belirlenmesi ve belirlenen özellikler dikkate alınarak kültürel önlemler içerisinde önemli bir yer tutan gübrelemenin doğru yapılması gerekmektedir (Bellitürk 2011). Vermikompost, tarımsal üretimde son yıllarda oldukça yaygınlaşan bir materyal olup birçok organik materyalin solucanlar tarafindan sindirilmesiyle elde edilen çevre dostu olan önemli bir organik gübredir (Şimşek Erşahin 2007). Farklı oranlarda uygulanan vermikompostun açık alan koşullarında yerleştirilen kıvırcık marulun gelişiminde, erkencilik özelliği üzerinde önemli etkide bulunduğu saptanmıştır (Hınısl 2014). Eşit miktarlarda toprak, torf ve perlit karışımına uygulanan farklı dozlardaki vermikompostun $5 \mathrm{BB}$ ve Trakya İlkeren aşı kombinasyonu uygulanan asma fidanları tarafindan alınan fosfor (P) miktarını arttırdığı tespit edilmiştir (Açıkbaş 2016). Ayçiçeği bitkisine farklı dozlarda uygulanan vermikompostun verim üzerinde önemli artışlara neden olduğu, bitki analiz sonuçlarına göre artan vermikompost dozlarına paralel olarak fosfor miktarını arttığı belirlenmiştir (Büyükfiliz 2016). Vermikompostun soğan, sarımsak, maydanoz ve semizotu gibi bazı bitkilerin gelişiminini ve toprak özelliklerini olumlu yönde etkilediği, artan vermikompost uygulamaları ile bitkilerde Mn miktarının azaldığı ve $\mathrm{Zn}$ miktarının ise arttığı, $\mathrm{Ca}$ ve $\mathrm{Mg}$ miktarının vermikompostun belli bir düzeyine kadar arttı̆̆ artırılmaya devam edildiğinde $\mathrm{Ca}$ ve $\mathrm{Mg}$ miktarında azalma olduğu saptanmıştır (Eryüksel 2016). Vermikompostun artan dozlarının toprak ortamına karıştırılarak 1spanak bitkisinde uygulanan vermikompost miktarının artışına bağlı olarak verim, bitki boyu, yaprak boyu ve eni, kök ağırlığı değerlerinin önemli düzeyde arttığı, toprağın verimlilik özelliklerinden olan toprak reaksiyonu ve P kapsamına etkisinin istatiksel anlamda önemli bulunduğu bildirilmiştir (Müftüoğlu ve ark. 2016).

Kireçli toprağa hümik asit ve fosforun mısır bitkisine birlikte uygulanması ile hümik asit miktarlarının bitki kuru ağırlığını, bitkideki toplam P miktarını ve topraktaki alınabilir P miktarını artırdığını, hümik asitin tek başına uygulanmasına göre $\mathrm{P}$ ile birlikte uygulanmasının daha etkili olduğu saptanmıştır (Erdal ve ark. 2000). Kentsel arıtma çamurunun mısırda fosfor kaynağı olarak kullanılma olanaklarının araştırıldı ̆̆ı çalışmada, kök kuru ağırlığı ve bitki mangan içeriğ etkilenmez iken, bitki bakır içeriğinin önemli düzeyde azaldığı, bitkinin toplam kuru ağırlı̆ıının önemli düzeyde arttığ1 belirlenmiştir (Çimrin ve ark. 2000). Fosfor ve mikoriza uygulamalarının marul bitkisinin verim özelliklerinde önemli artışlar elde edildiği, mikoriza uygulamaları ile bitki çap1 ve bitki kuru ağırlığında önemli artışlar olduğu, diğer verim özelliklerinde meydana gelen artışların ise istatiksel olarak önemli olmadığı, bitkinin $\mathrm{P}$ alımının yapılan $\mathrm{P}$ uygulamalarından önemli derecede etkilendiğini, en yüksek $\mathrm{P}$ alımının $200 \mathrm{mg} \mathrm{P}_{2} \mathrm{O}_{5} \mathrm{~kg}^{-1}$ uygulamasında ve en düşük $\mathrm{P}$ alımının ise $\mathrm{P}$ uygulaması yapılmayan kontrol uygulamasında gerçekleştiğini, mikoriza uygulamalarının da bitkinin P alımını istatiksel olarak önemli düzeyde artırdığ 1 bildirilmiştir (Ergin 2006). İki farklı marul çeşidine (Grand Rapids, Romaine) uygulanan farklı P düzeylerinin her iki marul çeşidinin de verim üzerinde olumlu sonuçlar meydana getirdiği ortaya konmuştur (Ahmed ve ark. 2013). Farklı P miktarları uygulanan marul bitkisinde, $\mathrm{P}$, brom $(\mathrm{Br})$, rubidyum $(\mathrm{Rb})$ konsantrasyonlarının artan $\mathrm{P}$ uygulamalarına paralel olarak arttığ 1 , ancak $\mathrm{Ca}$, kükürt (S), Fe, $\mathrm{Zn}, \mathrm{Mn}$, titanyum (Ti), stronsiyum ( $\mathrm{Sr}$ ) ve baryum (Ba) içeriklerinin ise azaldığı ve silisyum $(\mathrm{Si})$ ve nikel $(\mathrm{Ni})$ miktarlarında önemli bir değişim olmadığ saptanmıştır. Artan P uygulamalarının marul bitkisinin $\mathrm{K}$ içeriği üzerine etkisinin önemsiz olduğu, yüksek P düzeylerinin $\mathrm{S}$ miktarını azalttığı, $\mathrm{Fe}$ konsantrasyonu artan P uygulamasıyla azaldığı, artan düzeyde uygulanan $\mathrm{P}$ ile bitkilerin mikro bitki besin maddeleri miktarında artışlar olduğu, bu artışların çevre kirliliğini artırmasının yanında insan sağlığını da olumsuz etkilediği ve dolayısıyla fosforlu gübre kullanımında dikkatli davranılması ve aşırı kullanımlardan sakınılması gerektiği bildirilmiştir (Şahin ve ark. 2016).

Toprağın sürdürülebilir verimliliği için önemli organik maddece zengin olan vermikompost alternatif bir gübre kaynağ 1 haline gelmiştir. Organik gübre kullanımına bağlı olarak gelecek nesillere bırakacak olduğumuz topraklarımızın sürdürülebilirliği sağlanmış olacaktır. Kurulmuş olan bu denemede perlit, vermikompost ve farklı dozlarda fosfor kullanılarak oluşturulan ortamda yetiştirilen marul bitkisi tarafından fosfor alınımının incelenmesi amaçlanmıştır.

\section{Materyal ve Yöntem}

Denemede bitki materyali olarak torf ortamında yetiştirilmiş olan 35 günlük kıvırcık marul (Lactuca sativa L. var. crispa, cv.) fideleri, yetiştirme ortamı olarak tarım perliti, organik gübre olarak bir firmadan temin edilen vermikompost kullanılmıştır. Deneme 5 farklı fosfor dozu ve 4 tekerrürlü olarak tesadüf parselleri faktöriyel deneme desenine göre kurulmuştur. Vermikompostun $\mathrm{pH}$ (1 torf:10 saf su) değeri 6.60, suda çözünebilir tuz değeri $2.60 \mathrm{dS} \mathrm{m}^{-1}$, organik madde $\% 45.51$ olarak belirlenmiş, diğer özellikleri ise Çizelge 1 'de verilmiştir.

Çizelge 1. Denemede kullanılan vermikompostun bazı özellikleri.

Table 1. Some characteristics of vermicompost used in the experiment.

\begin{tabular}{|c|c|c|}
\hline \multirow[b]{2}{*}{ Element } & Suda çözünmüş & Kuru yakma \\
\hline & \multicolumn{2}{|c|}{$\operatorname{Miktar}\left(\mathrm{mg} \mathrm{kg}^{-1}\right)$} \\
\hline Fosfor (P) & 193.62 & 3896.96 \\
\hline Potasyum (K) & 6683.93 & 10137.39 \\
\hline Kalsiyum (Ca) & 326.06 & 29559.38 \\
\hline Magnezyum (Mg) & 159.71 & 4886.91 \\
\hline $\operatorname{Demir}(\mathrm{Fe})$ & 15.90 & 5958.14 \\
\hline Mangan (Mn) & 0.86 & 230.97 \\
\hline Çinko (Zn) & 0.39 & 120.65 \\
\hline Bakır $(\mathrm{Cu})$ & 1.27 & 68.37 \\
\hline Bor (B) & 4.44 & 6.93 \\
\hline
\end{tabular}

Deneme, 20.11.2017-24.02.2018 tarihleri arasındaki vejetasyon döneminde 3.51 hacimdeki saksılarda yürütülmüştür. Saksılara hacim esasına göre perlit doldurulmuş ve organik gübre olarak $1000 \mathrm{~kg} \mathrm{da}{ }^{-1}$ vermikompost ilave edilmiştir. Bitkinin bir vejetasyon döneminde gelişmesi için gerekli saf besin maddesi miktarlarını sağlamak için azot kaynağı olarak amonyum sülfat $(\% 21 \mathrm{~N})$, potasyum kaynağı olarak potasyum sülfat $\left(\% 51 \quad \mathrm{~K}_{2} \mathrm{O}\right)$ gübresi kullanılmıştır. Bitkinin fosfor gereksinimi fosforun değişik dozları $\left(0 ; 5 ; 10 ; 15 ; 20 \mathrm{~kg} \mathrm{\textrm {P } _ { 2 } \mathrm { O } _ { 5 }}\right.$ $\mathrm{da}^{-1}$ ) ile karşılanmış olup triplesüper fosfat (TSP, \%42 $\mathrm{P}_{2} \mathrm{O}_{5}$ ) gübre çözeltisi olarak saksılara ilave edilmiştir. Deneme sürecinde bitkiler hasat dönemine kadar gereksinim gösterdikleri aralıkta ve miktarda saf su ile sulanmıştır.

Hasat edilen bitkide incelenen özellikler aşağıda belirtilmiştir.

Verim $\left(\mathrm{g} \mathrm{bitki}^{-1}\right)$ : Her uygulamaya ait olan bitkilerin hasat edilerek alınan toprak üstü aksamları tartılmış, tartımların ortalamas1 alınarak her uygulamaya ait olan ortalama bitki ağırlığı bulunmuştur. 
Kök ağırlığı (g bitki $\left.{ }^{-1}\right)$ : Kökün üzerindeki perlit ve vermikompost kalıntıları saf su ile temizlendikten sonra kök üzerindeki nem kurutma kâğıdı ile kurulanarak terazide tartılması ile belirlenmiştir.

Bitki boyu $(\mathrm{cm})$ : Bitkinin toprak üstü aksamının kök boğazından itibaren en yüksek noktasına kadar olan mesafenin cetvel ile ölçülmesi ile saptanmıştır.

Bitki çapı (cm): Bitki başının en dar ve en geniş yerlerinden cetvel ile alınan ölçümlerin ortalamasının alınması ile tespit edilmiştir.

Yaprak sayısı (adet bitki-1): Bitkideki yaprak sayılarının sayılması ile bulunmuştur.

Yaprak ağırlığı (g yaprak $\left.{ }^{-1}\right)$ : Bitki veriminin bitkideki yaprak sayısına bölünmesi ile hesap edilmiştir.

Toplam fosfor $\left(\mathrm{mg} \mathrm{kg}^{-1}\right)$ : Hasat edilen marul bitkileri kurutma ve öğütme işlemlerinden sonra kuru yakma işlemi uygulanmış (Kacar ve İnal 2010), elde edilen bitki çözeltisindeki fosforun; vanadat ve molibdatın oksijenlerinin fosfat iyonu $\left(\mathrm{PO}_{4}^{-3}\right)$ ile yer değiştirmeleri sonunda oluşan kromojenik heteropoli bileşiğinden kaynaklanan sarı renk yoğunluğunun spektrofotometrede belirlenmesi esasına göre belirlenmiştir (Kitson ve Mellon 1944; Barton 1948).

$100 \mathrm{~g}$ tüketim ile alınan fosfor miktarı (g): Marul bitkisinden $100 \mathrm{~g}$ tüketildiğinde tüketici tarafından alınan fosfor miktarı yaş ağırlık üzerinden hesaplanmıştır.

Toplam verim ile sömürülen fosfor miktarı $(\mathrm{g})$ : Bitkinin verimi oluşturması için bulunduğu ortamdan almış olduğu fosfor miktarının yaş ağırlık üzerinden hesaplanması ile bulunmuştur.

Deneme sonucunda kaydedilen veriler MINITAB 18.0 istatistik paket programından yararlanılarak varyans analizi uygulanmış olup incelenen özelliklerden önemli olanlar F testi ile belirlenmiştir. Önemlilik dereceleri ise çoklu karşılaştırma testlerinden LSD testi ile değerlendirilmiştir.

\section{Bulgular ve Tartışma}

\subsection{Morfolojik özellikler}

Vermikompost uygulanmış olan perlit ortamına ilave edilen fosforun verim, kök ağırlığı, boy, çap, yaprak sayısı ve yaprak ağırlığına ait olan değerler Çizelge 2'de verilmiştir. Çizelge 2 incelendiğinde, verimin $52.00 \mathrm{~g} \mathrm{bitki}^{-1}$ ile $68.69 \mathrm{~g} \mathrm{bitki}^{-1}$ arasında değiştiği, fosfor verilen bitkilerdeki verimin kontrole göre daha fazla olduğu, verilen fosfor miktarları ile çok düzenli olmamakla birlikte verimin de arttığı, en fazla verim değerine $20 \mathrm{~kg} \mathrm{P} \mathrm{O}_{5} \mathrm{da}^{-1}$ dozunda ulaşıldı $\breve{g}_{1}$ görülmüştür. Perlit ortamına ilave edilmiş olan sabit dozdaki vermikompost ile farklı dozdaki fosforun marul bitkisinin verimi üzerine istatistiki açıdan etkisinin olmadığı görülmüştür. Özkan ve ark. (2016) farklı bitkilerde yapılan çalışmalar vemikompostun verimi istatistiksel olarak arttırdığını göstermiş̧tir. Adhami ve ark. (2014) yaptıkları çalışmada vermikompost oluşumu ve organik maddenin ayrışması sırasında ortama malonik asit, fumarik asit, süksinik asit gibi birçok organik bileşiklerin verildiğini ve böylece bitki besin maddelerinin yarayışlılığının arttığını bildirmiştir. Diğer bir çalışmada Pramanik ve ark. (2009), 90 günlük inkübasyonun sonunda vermikompostun topraktaki yarayışlı fosfor miktarını \%13-26 oranında artırdığını rapor etmiştir. Ayrıca Aria ve ark. (2010) vermikompostun kaya fosfatta bulunan suda çözünebilir fosfor miktarını olumlu etkilediğini bildirmiştir. Güneri ve ark. (2016), artan düzeylerde ve birlikte uygulanan fosfor ve potasyumun kamkat bitkisinin fidan gelişimi, verim düzeyi, meyve özellikleri ve beslenme düzeylerine etkisini araştırdıkları çalışmalarında; istatistiki düzeyde önemli olmamakla birlikte, $40 \mathrm{mg} \mathrm{kg}^{-1}$ fosfor ve $300 \mathrm{mg} \mathrm{kg}^{-1}$ potasyumun dozlarının kök uzunluğu, meyve ağırlığı, meyve sayısı ve meyve verimini arttırdığını belirtmişlerdir. Mtua ve ark. (2015), artan seviyelerde sıvı TKİ-Hümas ve $\mathrm{P}$ uygulamalarının fasulye bitkisinin verimi üzerine hem TKİ-Hümas hem de fosfor uygulamalarının etkisi istatistiki bakımdan önemli bulunmuş, bitkilerin beslenmesi, ekonomik olması ve verimin artırılması bakımından $12 \quad 1 \mathrm{da}^{-1} \quad$ TKİ-Hümas ve $5 \mathrm{~kg} \mathrm{P}_{2} \mathrm{O}_{5} \mathrm{da}^{-1}$ kombinasyonun önerilebileceği belirtilmiştir.

Kök ağırlığının $16.64 \mathrm{~g}$ bitki $^{-1}$ ile $20.65 \mathrm{~g} \mathrm{bitki}^{-1}$ arasında değiştiği, verilen fosfor miktarları ile çok düzenli olmamakla birlikte kök ağırlığının da azaldığı, perlit ortamına ilave edilmiş olan vermikompost ve farkli dozlardaki fosforun marul bitkisinin kök ağırlığı üzerine etkisinin istatistiksel açıdan önemli olmadığı saptanmıştır. Özkan ve ark. (2016), topraklara uygulanan vermikompostun bitkilerin gelişmesini desteklediğini, bitki kök gelişimini istatistiksel olarak arttırdığını belirtmiştir.

Bitki boyu değerlerinin $8.50 \mathrm{~cm}$ ile $11.67 \mathrm{~cm}$ arasında değiştiği, verilen fosfor dozunun artışına paralel olarak bitki boyunda da artış olduğu, perlit ortamına ilave edilmiş olan vermikompost ve farklı dozlardaki fosforun marul bitkisinin boyu üzerinde istatistiki açıdan etkisinin olmadığı görülmüştür. Domates bitkisinde yapılan çalışmalar, vemikompostun bitki boyunu istatistiksel olarak arttırdığını göstermiştir. Yıldırım ve ark. (2004) farklı azot ve fosfor dozlarının aspir bitkisinin boyu üzerine azotlu gübre dozlarının \%1 seviyesinde, fosforlu gübre dozları ile azot ve fosforlu gübre dozu interaksiyonun etkisi ise $\% 5$ seviyesinde önemli olduğunu, fosfor dozlarının bitki boyunu olumlu etkilediğini belirtmişlerdir.

Bitki çap1 değerlerinin $16.94 \mathrm{~cm}$ ile $19.06 \mathrm{~cm}$ arasında değiştiği, fosfor verilen bitkilerdeki meyve çapı miktarlarının kontrole göre daha geniş olduğu belirlenmiş, perlit ortamına ilave edilmiş olan vermikompost ve farklı dozlardaki fosforun

Çizelge 2. Verim, kök ağırlığı, boy, çap, yaprak sayısı ve yaprak ağırlı̆̆ı değerleri.

Table 2. Yield, root weight, height, diameter, number of leaves and leaf weight values.

\begin{tabular}{ccccccc}
\hline $\begin{array}{c}\text { Uygulama } \\
\left(\mathrm{kg} \mathrm{P}_{2} \mathrm{O}_{5} \mathrm{da}^{-1}\right)\end{array}$ & $\begin{array}{c}\text { Verim } \\
\left(\mathrm{g} \mathrm{bitki}^{-1}\right)\end{array}$ & $\begin{array}{c}\text { Kök ağırlı̆̆ } \\
\left(\mathrm{g} \mathrm{bitki}^{-1}\right)\end{array}$ & $\begin{array}{c}\text { Bitki boyu } \\
(\mathrm{cm})\end{array}$ & $\begin{array}{c}\text { Bitki çap1 } \\
(\mathrm{cm})\end{array}$ & $\begin{array}{c}\text { Yaprak sayıs1 } \\
\left(\text { adet bitki }^{-1}\right)\end{array}$ & $\begin{array}{c}\text { Yaprak ağırlı̆̆ } \\
(\mathrm{g} \text { yaprak }\end{array}$ \\
\hline 0 & 52.00 & 20.65 & 8.50 & 16.94 & $23.25 \mathrm{~B}$ & 2.21 \\
5 & 57.56 & 16.64 & 10.50 & 18.56 & $24.00 \mathrm{~B}$ & 2.40 \\
10 & 64.79 & 19.43 & 10.88 & 19.06 & $26.50 \mathrm{~A}$ & 2.45 \\
15 & 54.16 & 18.24 & 11.33 & 19.00 & $24.33 \mathrm{~B}$ & 2.23 \\
20 & 68.69 & 19.61 & 11.67 & 18.50 & $24.33 \mathrm{~B}$ & 2.83 \\
\hline $\mathrm{P}$ & $0.244^{\text {ÖD }}$ & $0.731^{\text {ÖD }}$ & $0.224^{\circ 0}$ & $0.352^{\text {ÖD }}$ & $0.007^{* *}$ & $0.518^{\text {ÖD }}$ \\
\hline
\end{tabular}

ÖD: Önemli değil, **: \%1 düzeyinde önemli. 
marul bitkisinin çapı üzerinde istatistiki açıdan etkisinin olmadığ1 görülmüştür. Güneri ve ark. (2016), artan düzeylerde ve birlikte uygulanan fosfor ve potasyumun kamkat bitkisinin fidan gelişimi, meyve özellikleri, verim ve beslenme düzeylerine etkisini araştırdıkları çalışmalarında, istatistiksel olarak önemli bulunmamakla birlikte fosfor uygulamalarının anaç çapı artışı sağladığını belirtmişlerdir.

Yaprak sayısı değerlerinin 23.25 adet bitki ${ }^{-1}$ ile 26.50 adet bitki ${ }^{-1}$ arasında değiştiği, fosfor verilen bitkilerdeki yaprak sayılarının kontrole göre $10 \mathrm{~kg} \mathrm{P}_{2} \mathrm{O}_{5} \mathrm{da}^{-1}$ dozuna kadar arttığ 1 , $10 \mathrm{~kg} \mathrm{P}_{2} \mathrm{O}_{5} \mathrm{da}^{-1}$ dozunda maksimum seviyeye ulaştı̆̆ 1 ve bu değişimin kontrole göre önemli olduğu ve $10 \mathrm{~kg} \mathrm{P}_{2} \mathrm{O}_{5} \mathrm{da}^{-1}$ dozundan $20 \mathrm{~kg} \mathrm{P}_{2} \mathrm{O}_{5} \mathrm{da}^{-1}$ dozuna kadar azaldığı görülmüştür. Perlit ortamına ilave edilmiş olan vermikompost ve farklı dozlardaki fosforun marul bitkisinin yaprak sayısı üzerine etkisi istatistiksel açıdan \%1 düzeyinde önemli bulunmuştur. Çıtak ve ark. (2011) tarafindan ispanak bitkisine vermikompost ve ahır gübresi uygulanmalarının yaprak sayısı, yaprak sap kalınlığı, yaprak sap uzunluğu, bitki boyu, gövde kalınlığı ve verim parametreleri açısından istatistiksel olarak önemli etkide bulunduğu saptanmıştır.

Yaprak ağırlıklarının $2.21 \mathrm{~g}$ yaprak$^{-1}$ ile $2.83 \mathrm{~g}$ yaprak $^{-1}$ arasında değiştiği, fosfor verilen bitkilerdeki yaprak ağırlığının kontrole göre daha fazla olduğu, verilen fosfor miktarları ile çok düzenli olmamakla birlikte yaprak ağırlığının da arttığı, en fazla yaprak ağırlığına $20 \mathrm{~kg} \mathrm{P} \mathrm{P}_{2} \mathrm{O}_{5} \mathrm{da}^{-1}$ dozunda ulaşıldığı, perlit ortamına ilave edilmiş olan vermikompost ve farklı dozlardaki fosforun marul bitkisinin yaprak ağırlığı üzerinde istatistiki açıdan etkisinin olmadığı görülmüştür.

\subsection{Fosfor miktarlart}

Vermikompost uygulanmış olan perlit ortamına ilave edilen fosforun toplam fosfor içeriğine, $100 \mathrm{~g}$ tüketim ile alınan fosfor miktarına ve bitkinin verimini oluşturmak için yetiştirildiği ortamdan sömürdüğü fosfor miktarına ait olan değerler Çizelge 3 'de verilmiştir. Çizelge 3 incelendiğinde, bitkideki toplam fosfor içeriği değerlerinin 701 ile $2928 \mathrm{mg} \mathrm{kg}^{-1}$ arasında değiştiği, toplam fosfor içeriğinin verilen $10 \mathrm{~kg} \mathrm{P} \mathrm{P}_{2} \mathrm{O}_{5} \mathrm{da}^{-1}$ uygulamasına kadar arttığı, bu dozdan sonra verilen fosfor miktarının bitkide rakamsal olarak bir artış meydana getirmediği hatta azalttığ1 görülmüştür. Kontrol uygulamasına göre tüm fosfor uygulamalarında bitkinin toplam fosfor içeriği istatistiksel olarak önemli oranda artmış ancak kontrol hariç diğer tüm fosfor uygulamaları arasındaki değişimler önemli bulunmamıştır. Perlit ortamına ilave edilmiş olan sabit dozdaki vermikompost ile farklı dozdaki fosforun marul bitkisinin toplam fosfor içeriği üzerine etkisi istatistiksel açıdan \%1 önemli olduğu görülmüş̧ür. Çıtak ve ark. (2011)'nın farklı dozlarda vermikompost ve ahır gübresi uygulamalarının toprağın verimliliği ve 1 spanak bitkisinin gelişimi araştırmak amacıyla tarla şartlarında ve kış periyodunda gerçekleştirilen denemede; toprakta bulunan azot, fosfor, potasyum ve magnezyum içeriklerine ahır gübresinin vermikompost uygulamalarına göre daha etkili olduğu tespit edilmiştir. Özkan ve Müftüoğlu (2016), vermikompost uygulamasının toprak verimlilik parametrelerinden, toprak reaksiyonu ve alınabilir fosfor üzerinde önemli olduğunu, bitki özelliklerinden ise sadece yaprak sayısı üzerinde olduğunu, bunun yanında toprak reaksiyonu üzerinde de etkili olduğu için fazla dozlardan kaçınılması gerektiğini belirtmişlerdir. Mtua ve ark. (2015), artan seviyelerde sıvı TKİ-Hümas ve P uygulamasının fasulye bitkisinin yapraklarının fosfor kapsamı üzerine hem TKİ-Hümas hemde fosfor uygulamalarının etkisinin istatistiki bakımdan önemli olduğu belirtilmiştir.

Vermikompost uygulanmış olan perlit ortamına ilave edilen fosforun marul bitkisinin $100 \mathrm{~g}$ tüketim ile alınan fosfor miktarlarının $3.50 \mathrm{~g}$ ile $23.70 \mathrm{~g}$ arasında değiştiği, fosfor verilen bitkilerdeki $100 \mathrm{~g}$ tüketim ile alınan fosfor miktarlarının 10 $\mathrm{kg} \mathrm{P}_{2} \mathrm{O}_{5} \mathrm{da}^{-1}$ dozuna kadar arttı̆̆ 1 ve marul bitkisinin içerdiğ fosfor miktarı ile paralellik göstererek $10 \mathrm{~kg} \mathrm{P}_{2} \mathrm{O}_{5} \mathrm{da}^{-1}$ dozunda maksimum seviyeye ulaştığı görülmüştür. Eşit miktarlarda tüketildiğinde en yüksek miktarda fosfor sağlayan 10 $\mathrm{kg} \mathrm{P}_{2} \mathrm{O}_{5} \mathrm{da}^{-1}$ dozundan $20 \mathrm{~kg} \mathrm{P}_{2} \mathrm{O}_{5} \mathrm{da}^{-1}$ dozuna doğru rakamsal bir azalma olmuş ancak istatistiksel olarak aynı grupta yer almışlardır. Perlit ortamına ilave edilmiş olan sabit dozdaki vermikompost ve farklı dozlardaki fosforun marul bitkisinin $100 \mathrm{~g}$ tüketim ile alınan fosfor miktarı üzerine etkisinin istatistiksel açıdan \%1 düzeyinde önemli olduğu belirlenmiştir.

Vermikompost uygulanmış olan perlit ortamına ilave edilen fosforun marul bitkisinin toplam verim ile sömürülen fosfor miktarı değerlerinin $1.87 \mathrm{~g}$ ile $15.11 \mathrm{~g}$ arasında değiştiği, kontrol uygulamasına göre verilen fosfor miktarları ile önemli oranda artan toplam verim ile sömürülen fosfor miktarlarına en fazla $10 \mathrm{~kg} \mathrm{P}_{2} \mathrm{O}_{5} \mathrm{da}^{-1}$ dozunda ulaşılmıştır. Perlit ortamına ilave edilmiş olan sabit dozdaki vermikompost ile farklı dozdaki fosforun marul bitkisinin verimi oluştururken toplam sömürdüğü fosfor miktarı üzerine üzerine etkisi istatistiksel açıdan \%1 düzeyinde önemli olduğu tespit edilmiştir.

\section{Sonuç}

Perlit ortamına $1000 \mathrm{~kg} \mathrm{da}^{-1}$ hesabı ile vermikompost ilave edilen ortamda yetiştirilen marul bitkisinin farklı fosfor dozları ile beslenmesinin verim, kök ağırlı̆̆ı, bitki boyu, bitki çapı, yaprak ağırlı̆̆ yaprak sayısı üzerine ise istatistiksel açıdan \%1 önemli etkide bulunduğu, yaprak sayılarının $10 \mathrm{~kg} \mathrm{P}_{2} \mathrm{O}_{5} \mathrm{da}^{-1}$ dozuna kadar $\operatorname{arttığı~bu~dozdan~sonra~azaldığı~saptanmıştır.~Farklı~fosfor~}$

Çizelge 3. Bitkideki toplam fosfor miktarı, $100 \mathrm{~g}$ tüketim ile alınan fosfor miktarı ve verim için ortamdan alınan fosfor miktarı.

Table 3. The total phosphorus amount in the plant, amount of phosphorus in $100 \mathrm{~g}$ green consumed plant, the amount of uptake phosphorus from the medium for yield.

\begin{tabular}{cccc}
\hline $\begin{array}{c}\text { Uygulama } \\
\left(\mathrm{kg} \mathrm{P}_{2} \mathrm{O}_{5} \mathrm{da}^{-1}\right)\end{array}$ & $\begin{array}{c}\text { Toplam fosfor miktarı } \\
(\mathrm{ppm}, \text { kuru ağırlık) }\end{array}$ & $\begin{array}{c}100 \mathrm{~g} \text { tüketim ile alınan fosfor miktarı } \\
(\mathrm{mg}, \text { yaş ağırlık })\end{array}$ & $\begin{array}{c}\text { Toplam sömürülen fosfor miktarı } \\
(\mathrm{mg}, \text { yaş ağırlık })\end{array}$ \\
\hline 0 & $701 \mathrm{~B}$ & $3.50 \mathrm{C}$ & $1.87 \mathrm{D}$ \\
5 & $2135 \mathrm{~A}$ & $12.77 \mathrm{~B}$ & $7.27 \mathrm{C}$ \\
10 & $2928 \mathrm{~A}$ & $23.70 \mathrm{~A}$ & $15.11 \mathrm{~A}$ \\
15 & $2425 \mathrm{~A}$ & $19.03 \mathrm{AB}$ & $10.24 \mathrm{BC}$ \\
20 & $2475 \mathrm{~A}$ & $18.22 \mathrm{AB}$ & $12.40 \mathrm{AB}$ \\
\hline $\mathrm{P}$ & $0.002^{* *}$ & $0.000^{* *}$ & $0.000^{* *}$ \\
\hline
\end{tabular}


dozları ile beslenmesinin marul bitkisi tarafından alınan toplam fosfor değerleri üzerine istatistiksel açıdan \%1 önemli olduğu, verilen fosforun $10 \mathrm{~kg} \mathrm{P}_{2} \mathrm{O}_{5} \mathrm{da}^{-1}$ dozuna kadar bitki tarafindan alındığı, bu dozdan sonra verilen fosfor miktarının bitkide bir artış meydana getirmediği belirlenmiştir.

Marulun $100 \mathrm{~g}$ tüketimi ile tüketiciye sunmuş olduğu toplam fosfor içeriğinin istatistiksel açıdan \%1 seviyesinde önemli olduğu, fosfor verilen bitkilerdeki alınan fosfor miktarlarının $10 \mathrm{~kg} \mathrm{P}_{2} \mathrm{O}_{5} \mathrm{da}^{-1}$ dozuna kadar arttığ 1 , marul bitkisinin içerdiği fosfor miktarı ile paralellik göstererek 10 $\mathrm{kg} \mathrm{P}_{2} \mathrm{O}_{5} \mathrm{da}^{-1}$ dozunda maksimum seviyeye ulaştığ 1 görülmüştür. Eşit miktarlarda tüketildiğinde en yüksek miktarda fosfor sağlayan $10 \mathrm{~kg} \mathrm{P}_{2} \mathrm{O}_{5} \mathrm{da}^{-1}$ dozundan $20 \mathrm{~kg} \mathrm{P}_{2} \mathrm{O}_{5} \mathrm{da}^{-1}$ dozuna doğru bir azalma olduğu ancak bu iki grubun da istatistiksel olarak aynı grupta yer aldığı belirlenmiştir. Farklı fosfor dozları ile beslenmenin, marul bitkisinin verimini oluşturmak için ortamdan sömürdüğü fosfor miktarı üzerine istatistiksel açıdan $\% 1$ önemli etki ettiği, en fazla sömürülen fosforun 10 $\mathrm{kg} \mathrm{P}_{2} \mathrm{O}_{5} \mathrm{da}^{-1}$ dozu olduğu saptanmıştır.

Sonuç olarak; marul bitkisindeki fosfor miktarının, uygulanan $10 \mathrm{~kg} \mathrm{P}_{2} \mathrm{O}_{5} \mathrm{da}^{-1}$ miktarına kadar arttığ $\breve{1}_{\text {, bu dozdan }}$ sonra verilen fosfor miktarının bitkideki fosfor miktarında bir artış meydana getirmediği hatta azaldığı saptanmıştır. Bitkilerden yeşil olarak $100 \mathrm{~g}$ tüketilmesi durumunda alınan fosfor miktarının $10 \mathrm{~kg} \mathrm{P}_{2} \mathrm{O}_{5} \mathrm{da}^{-1}$ dozuna kadar arttığı, bu dozdan sonra azalma olduğu tespit edilmiştir. Marul bitkisinin verimi oluştururken ortamdan en fazla fosforu $10 \mathrm{~kg} \mathrm{P}_{2} \mathrm{O}_{5} \mathrm{da}^{-1}$ dozunda sömürdüğü tespit edilmiştir.

Bitkinin eşit miktarda verilen vermikompostun yanı sıra farklı fosfor dozları ile beslenmesi durumunda, gereksinimi kadar fosfor aldığı, hareketi az olan fosfor elementinin alımında vermikompostun yeterince etkisinin izlenemediği, konu ile ilgili olarak farklı çalışmaların yapılması gerektiği, farklı özellikteki vermikompostların bitkilerin beslenmesi üzerinde farklı etkiler yapacağı bu nedenle farklı sonuçlar elde edilebileceği sonucuna varılmıştır.

\section{Kaynaklar}

Açıkbaș B (2016) Vermikompostun 5 BB üzerine aşılı Trakya İlkeren asma fidanlarının bitki besin elementi içerikleri ve vejetatif gelişmesine etkisi. Yüksek Lisans Tezi. Namık Kemal Üniversitesi, Tekirdağ.

Adhami E, Hosseini S, Owliaie H (2014) Forms of phosphorus of vermicompost produced from leaf compost and sheep dung enriched with rock phosphate. International Journal of Recycling of Organic Waste in Agriculture 3: 68.

Ahmed SS, Khan MA, Sani IA, Sharif M, Shahwani MN, Afridi S, Ahmed N (2013) Marul (Lactuca sativa L.) Çeşitlerinin tohum verimi ve vejetatif gelişimi üzerine fosfor düzeylerinin etkisi. Çanakkale Onsekiz Mart Üniversitesi Ziraat Fakültesi Dergisi 1(1): 95-100.

Aria MM, Lakzian A, Haghnia GH, Berenji AR, Besharati H, Fotovat A (2010) Effect of Thiobacillus, sulfur, and vermicompost on the water-soluble phosphorus of hard rock phosphate. Bioresource Technology 101(2): 551-554.

Barton CJ (1948) Photometric analysis on phosphate rock. Analitical Chemistry 20(11): 1068-1073.

Bellitürk K (2011) Edirne ili Uzunköprü ilçesi tarım topraklarının beslenme durumlarının belirlenmesi. Tekirdağ Ziraat Fakültesi Dergisi 8(3): 8-15.

Büyükfiliz F (2016) Vermikompost gübrelemesinin ayçiçeği (Helianthus annuus L.) bitkisinin verim ve bazı kalite parametreleri üzerine etkisi. Yüksek Lisans Tezi. Namık Kemal Üniversitesi,

\section{Tekirdağ.}

Çıtak S, Sönmez S, Koçak F, Yaşin S (2011) Vermikompost ve ahır gübresi uygulamalarının ıspanak (Spinacia Oleracea Var. L.) bitkisinin gelişimi ve toprak verimliliği üzerine etkileri. Batı Akdeniz Tarımsal Araştırma Enstitüsü Derim Dergisi 28(1): 56-69.

Çimrin KM, Bozkurt MA, Erdal İ (2000) Kentsel arıtma çamurunun tarımda fosfor kaynağı olarak kullanılması. Yüzüncü Y1l Üniversitesi Tarım Bilimleri Dergisi 10(1): 85-90.

Erdal İ, Bozkurt MA, Çimrin KM, Karaca S, Sağlam M (2000) Kireçli bir toprakta yetiştirilen mısır bitkisi (Zea mays L.) gelişimi ve fosfor alımı üzerine hümik asit ve fosfor uygulamasının etkisi. Turkish Journal of Agriculture and Forestry 24: 663-668.

Ergin SF (2006) Mikorizanın Marul Bitkisinde Bitki Gelişimi ve Fosfor Alımı Üzerine Etkileri, Yüksek Lisans Tezi, Yüzüncü Yıl Üniversitesi, Van.

Eryüksel S (2016) Farklı oranlarda vermikompost uygulamasının bazı sebzelerin besin elementi içeriklerine olan etkileri. Yüksek Lisans Tezi. Namık Kemal Üniversitesi, Tekirdağ.

Güneri M, Akat H, Yağmur B, Yokaş İ (2016) Farklı fosfor ve potasyum düzeylerinin Kamkat (Fortunella margarita (Lour.) Swing)'ın büyüme ve gelişimine etkileri. Gaziosmanpaşa Üniversitesi Ziraat Fakültesi Dergisi 33(1): 64-74.

Hınıslı N (2014) Vermikompost gübresinin kıvırcık bitkisinin gelişmesi üzerine etkisinin belirlenmesi ve diğer bazı organik kaynaklı gübrelerle karşılaştırılması. Yüksek Lisans Tezi. Namık Kemal Üniversitesi, Tekirdağ.

Kacar B, İnal A (2010) Bitki Analizleri. Nobel Yayınevi, ISBN: 978605-395-036-3, s. 912.

Kitson RE, Mellon MG (1944) Colorimetric determination of phosphorus as molybdovanadophosphoric acid. Industrial and Engineering Chemistry Analytical 16(6): 379-383.

Mtua KA, Gökmen Yilmaz F, Gezgin S (2015) Artan dozlarda TKİHümas ve fosfor uygulamaların kuru fasulye (Phaseolus vulgaris L.) bitkisinin gelişimine etkileri. Selçuk Tarım Bilimleri Dergisi 2(2): 84-90.

Müftüoğlu NM, Ünser E, Özkan N, Dağlığlu M (2016) Vermikompostun spanak (Spinacia oleracea L.) verimi ve bazı toprak özellikleri üzerine etkisi. Çanakkale Onsekiz Mart Üniversitesi Ziraat Fakültesi Dergisi 4(1): 1-5.

Özkan N, Müftüoğlu NM (2016) Farklı dozlardaki vermikompostun marul verimi ve bazı toprak özellikleri üzerine etkisi. Bahçe, Yalova Atatürk Bahçe Kültürleri Araştırma Enstitüsü Dergisi, ISSN 1300-8943, Cilt: 45, Yıl: 2016, Sayı: Özel sayı, VII. Ulusal Bahçe Bitkileri Kongresi, 25 - 29 Ağustos 2015, Çanakkale, Cilt:2: Sebzecilik-Bağcılık-Süs Bitkileri, s. 121-124.

Pramanik P, Bhattacharya S, Bhattacharyya P, Banik P, (2009) Phosphorous solubilization from rock phosphate in presence of vermicomposts in Aqualfs. Geoderma 152: 16-22.

Şahin Ö, Taşkın MB, Kaya EC (2016) Fosfor uygulamasının marul ve soğan bitkilerinin mineral element konsantrasyonlarına etkisi. Nevşehir Bilim ve Teknoloji Dergisi TARGID Özel Sayı: 150-160.

Şimşek Erşahin Y (2007) Vermikompost ürünlerinin eldesi ve tarımsal üretimde kullanım alternatifleri. Gaziosmanpaşa Üniversitesi Ziraat Fakültesi Dergisi 24(2): 99-107.

Yıldırım B, Tunçtürk M, Dede Ö, Okut N (2004) Aspir (Carthamus tinctorius L.)'de farklı azot ve fosfor dozlarının verim ve kalite üzerine etkileri. Yüzüncü Yıl Üniversitesi Ziraat Fakültesi Tarım Bilimleri Dergisi 15(2): 113-117. 